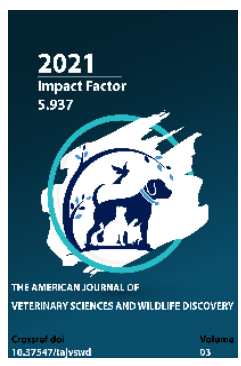

Journal Website: http://usajournalshub.c om/index,php/tajvswd

Copyright: Original content from this work may be used under the terms of the creative commons attributes 4.0 licence.

\section{Blood Indications In Echinococcosis Of Large Horned Animals}

\author{
Khidir Yuldashovich Arziev \\ Candidate Of Veterinary Sciences, Senior Research Fellow Veterinary Research Institute, \\ Uzbekistan
}

\author{
Shomurod Makhmudovich Rasulov \\ Senior Research Fellow Department Of Epidemiology, Tashkent Medical Academy, \\ Uzbekistan
}

\author{
Mansur Salomatovich Togaymurodov \\ Assistant Department Of Zooengineering, Veterinary And Silkworm Breeding Termez Branch \\ Of Tashkent State Agrarian University, Uzbekistan
}

\title{
ABSTRACT
}

This article presents the results of studying the prevalence of echinococcosis among large horned animals in the Samarkand and Surkhandarya regions and hematological blood parameters in animals heavily or weakly infected with echinococcus in the wild. In Samarkand region, $8.8 \%$ of cattle were infected with echinococci, and in Surkhandarya region - 14.3\%. Decrease in the amount of erythrocytes and hemoglobin in the blood of cattle infected with echinococcosis (20-30\%), increase in the number of leukocytes by $30-55 \%$, and a significant increase in the number of eosinophils and lymphocytes in the leukoform, a decrease in neutrophils compared to control (3.25-6.5\%). lymphocytes increased by $5 \cdot 3-15 \cdot 3 \%$.

\section{KEYWORDS}

Veterinary, parasite, helminth, deworming, prophylaxis, oncosphere, larvae, protoscolex, praziquantel, piperazine, febantel, arecoline, preparation, echinococcosis, phenasal, pyrantel, bunamidine, mebendazole, nitroscanate, fenbendazo, fenbenda politrem.

\section{INTRODUCTION}

Providing the population of the republic with quality livestock (meat and dairy products) is an urgent problem of our time. It is known that many infectious and parasitic diseases, 
including helminthiasis, are adapted to a particular animal, group of animals or the human body, and it is these organisms that enter the body and cause specific diseases. As a result, the productivity of the animals decreases or stops altogether. Such helminthiases include helminthiasis such as teniarinhoz (bull solitary), teniosis (pig solitary), echinococcosis.

The most common of these helminthiases are larval cestodes, which cause great harm to animals, including livestock and humans, and are dangerous.

Helminthozoonoses infect farm animals and cause economic damage. That is, it has a negative impact on the development of the national economy. This economic damage is caused by the cost of veterinary and sanitary measures against the disease, a sharp decline in the productivity of infected animals and the death of infected animals.

N.M.Matchanov, A. T. According to Sagieva, V.M. Sodiqov (1977), when animals imported from farms of Samarkand region were slaughtered and examined at the meat-packing plant, 2923 out of 6056 sheep (48.2\%), 287 out of 2543 head of cattle $(11.28 \%)$, Out of 6712 heads of pigs 240 heads (3.58\%), 112 heads of camels 39 heads (34.8\%), 1837 heads of goats 6 heads $(0.32 \%), 597$ heads of horses 5 heads, ie $0.83 \%$ were infected with echinococci detected.

According to M. Aminjanov's research (2003), echinococcosis is also increasing year by year among farm animals. In particular, 15 years ago the disease was $24.3 \%$ among cattle, $45.1 \%$ among sheep, $8.0 \%$ among goats, $25.4 \%$ among camels, $32.0 \%$ among donkeys and $15.0 \%$ among dogs. cattle - by $46.2 \%$, sheep - by $65.0 \%$, goats by $12.0 \%$, camels - by $35.0 \%$, donkeys - by $38 \%$ and dogs - by $24.3 \%$.
According to E.H. Ergashev and others (2000), the economic damage from echinococcosis is 5 billion soums a year.

According to S.A. Beer, R.S. Ermolova, Yu.I. Vaserin (1990), the cost per person with echinococcosis in Russia amounted to 15068400 rubles, in case of death - 79122500 rubles.

According to F.P. Kovalenko et al. (2000), the cost of operating on a person with echinococcosis in the Russian Federation ranged from $\$ 800$ to $\$ 1,400$.

According to Bartelli G., Martini M. (1992), the annual cost of combating human and animal echinococcosis in the Italian province of Sardinia is 23 billion liras.

Dogs are the main hosts of a number of parasitic and infectious pathogens, carrying their pathogens and constantly spreading them. Dogs can often transmit parasitic eggs when they are petted by humans and animals, but mainly when dogs excrete feces, they go to areas planted with greens, melons, fruits, vines, agricultural crops, take something with them and infect the walking helminth eggs. As a result, humans and animals become infected with the pathogen along with food. In recent years, thanks to the development of science, several hundred anthelmintics against helminthiasis in dogs have been discovered and their application schemes have been developed.

There are differing opinions among scientists about deworming schemes for dogs. Some scientists recommend that the structure and timing of deworming be determined by the laws of development of the parasite, some by the state of its spread, and still others by economic considerations. In any case, 
deworming requires the expulsion of parasitic worms from the dog's body.

According to I.A. Arkhipov (2001), Piperazine, Phenasal, Praziquantel, Pyrantel, Arekolin, Bunamidine, Mebendazole, Nitroscanate, Fenbendazole, Flubendazole, Oxybendazole, Antibolin, Antibolin, Febantel, Febantel, etc. is calculated. According to I.A. Subbotina, B.N. Bakyev (2018), in Turkmenistan, dogs are infected with echinococci by $28-57 \%$, and by multiceps - by $13-23 \%$.

According to O.N. Andreyev (2018), in the southeastern part of the Central Federal District of Russia, wild mammals are infected with various types of helminths by $37 \cdot 5-50.0 \%$. The total helminth infestation rate was $49.4 \%$.

According to B.K. Laypanov (2018), even deworming dogs 4 times a year does not fully protect people from echinococcosis. For the treatment of a person with echinococcosis in Russia spends 15,000 Russian rubles, only 8001400 US dollars for surgical removal of the echinococcal bladder.

The most dangerous disease among helminthiasis is echinococcosis. Therefore, we have analyzed below the changes observed in the form elements of the blood in the body of large horned animals of this disease.

\section{THE PURPOSE OF THE STUDY}

Study of hematological parameters in the blood of large horned animals infected with echinococcosis.
Research tasks: 1. Larval cestodes - to determine the prevalence of echinococcosis, cysticercosis and other helminthiases.

2. Analysis of blood counts of cattle infected with echinococcosis at high and moderate intensity and not infected with this helminthiasis.

\section{RESEARCH MATERIALS AND METHODS}

Monitoring of the spread of larval cestodes among cattle - large horned animals In Samarkand, Taylak, Jambay and Payarik districts of Samarkand region, as well as in Boysun district of Surkhandarya region, large horned animals slaughtered in poultry houses were inspected. Research methods in helminthology were carried out by KI Scriabin's TGYo, non-helminthological cracking (macro).

In the Helminthozoonosis Laboratory of the Veterinary Research Institute, blood counts of erythrocytes and leukocytes, hemoglobin content and leukocyte count were determined using high and moderate intensity echinococcosis, as well as the results obtained in hematology.

\section{INSPECTION RESULTS}

Studies to determine the prevalence of larval cestodes among large horned animals were conducted in Samarkand, Taylak, Jambay and Payarik districts of Samarkand region, as well as in Boysun district of Surkhandarya region.

The results of studies on helminthiasis in livestock are presented in Table 1. 


\section{Results of examination of cattle slaughtered for helminths in slaughterhouses}

Table 1

\begin{tabular}{|c|c|c|c|c|c|c|c|c|c|c|}
\hline \multirow{4}{*}{ № } & \multirow{4}{*}{ Provinces } & \multirow{4}{*}{$\begin{array}{c}\text { Number of } \\
\text { YSHs } \\
\text { checked } \\
\text { (head) }\end{array}$} & \multicolumn{8}{|c|}{ Pathogens found } \\
\hline & & & \multicolumn{4}{|c|}{ echinococci } & \multicolumn{4}{|c|}{ fasciolias } \\
\hline & & & \multicolumn{2}{|c|}{ IE } & \multicolumn{2}{|c|}{ II } & \multicolumn{2}{|c|}{ IE } & \multicolumn{2}{|c|}{ II } \\
\hline & & & head & $\%$ & liver & lung & $\begin{array}{c}\text { hea } \\
\text { d }\end{array}$ & $\%$ & Total & $\begin{array}{c}\text { averag } \\
\text { e }\end{array}$ \\
\hline 1 & Samarkand & 205 & 18 & 8,8 & $\begin{array}{c}162290 \\
0\end{array}$ & 42623,6 & 34 & 16,6 & 3103 & 91,3 \\
\hline 2 & $\begin{array}{c}\text { Surkhandar } \\
\text { yo }\end{array}$ & 7 & 1 & 14,3 & 7 & 3 & - & - & - & - \\
\hline & Total & 212 & 19 & 8,96 & 85,7 & 22,5 & 34 & 16,0 & 31,03 & 91,3 \\
\hline
\end{tabular}

According to the table, a total of 212 head of large horned animals were monitored. Of the 212 large horned animals examined, echinococcal vesicles were found in 19 heads (8.96\%), of which 1,622 in the liver and 426 in the lungs, i.e., 85.7 in intensive liver and 22.5 in the lungs, and 34 (16.0\%) fasciolia. and the invasion rate was 91.3 copies. In particular, echinococci were found in 18 (8.8\%) of 205 large horned animals examined in Samarkand region. Of these, 1,622 were detected in the liver and 426 in the lungs. Intens invasion was 90 and 23.6 copies, respectively. With fasciola, 34 heads (16.6\%) were infected and 3,103 copies of helminths were found. Intensity invasion was 91.3 copies.

Echinococci were found in 1 head (14.3\%) of 7 large horned animals examined in Surkhandarya region. Of these, 7 were detected in the liver and 3 in the lungs. Intens invasion was 7 and 3 copies, respectively. The causative agent of fasciolosis was not observed.

Hematological parameters of cattle infected with echinococcosis to varying degrees were examined. To do this, large horned animals slaughtered in the poultry house were divided into groups of 4 to 3 according to the degree of infection with echinococci. Group I - severely infected animals, ie in this group a total of: 682 copies in the liver, 181 copies in the lungs, an average of 170.5 copies in the lungs - 45.25 copies, in group II in this group of weakly affected: 121 in the liver, lungs -19 copies, on average 30.25 , in the lungs-4.75 copies of echinococcal vesicles were detected and group III was divided into uninfected animals. Blood was drawn from these cattle and the hematological parameters of the blood were checked by generally accepted methods.

The results of these studies are presented in Table 2.

The data show that the average amount of hemoglobin in the blood is $62.0 \pm 0.81$ in group I, $67.5 \pm 0.95$ in group II and $77.5 \pm 0.95 \mathrm{~g} / \%$ in group III, the average amount of erythrocytes I $-5.22 \pm 0.03$ in group, $5.71 \pm 0.03$ in group II and $7.1 \pm 0.01$ million $/ \mu$ in group III, the average number of leukocytes in group I - $12.67 \pm 0.36$, In group II it was $10.62 \pm 0.16$ and in group III it 
was $8.15 \pm 0.8$ thousand $/ \mu$ l. When determining the leukoformula, the average number of basophils in all three groups was $1 \%$, eosinophils averaged 11, $0 \pm 0$ in group I, $7.75 \pm 0$ in group II, and $4.5 \pm 0 \%$ in group III. In group I $-3.0 \pm 0$, in group II $-4.5 \pm 0$, and in group III $-6.5 \pm 0$, percent, the average amount of neutrophils with segment nuclei is $19.0 \pm 0$ in group I, 29 in group II , $0 \pm 0$, and in group III $-36.25 \pm 0$ percent, the average number of lymphocytes in group I - 61.0 \pm 0 , in group II - $53.0 \pm 0$, and in group III $-47.75 \pm 0$ percent. and the average amount of monocytes was $5.0 \pm 0$ percent in group I, $4.75 \pm 0$ percent in group II, and $4.0 \pm 0$ percent in group III.

Table 2

Hematological indicators of cattle infected with echinococcosis of varying intensity

\begin{tabular}{|c|c|c|c|c|c|c|c|c|c|c|c|}
\hline \multirow{3}{*}{ No } & \multirow{3}{*}{$\begin{array}{l}\text { Hemog } \\
\text { lobin } \\
\text { content } \\
\text { gr } / \%\end{array}$} & \multirow{3}{*}{$\begin{array}{c}\text { Erythr } \\
\text { ocyte } \\
\text { ml / } \\
\text { mkl }\end{array}$} & \multirow{3}{*}{$\begin{array}{c}\text { Leukocyt } \\
\text { e ming / } \\
\text { mkl }\end{array}$} & \multicolumn{8}{|c|}{ LEUKOFORMULA } \\
\hline & & & & \multirow{2}{*}{$\begin{array}{c}\mathbf{B a} \\
\mathbf{S}\end{array}$} & \multirow{2}{*}{ Eos } & \multicolumn{4}{|c|}{ Neutrophil } & \multirow{2}{*}{ Lym } & \multirow{2}{*}{ Mon } \\
\hline & & & & & & $\mathbf{M}$ & 10 & II & c & & \\
\hline Group I & 64 & 5,28 & 11,8 & 1 & 10 & - & - & 4 & 21 & 59 & 5 \\
\hline & 62 & 5,24 & 12,6 & 1 & 11 & - & - & 3 & 19 & 60 & 6 \\
\hline severely & 62 & 5,23 & 12,7 & 1 & 11 & - & - & 3 & 19 & 61 & 5 \\
\hline damaged & 60 & 5,14 & 13,6 & 1 & 12 & - & - & 2 & 17 & 64 & 4 \\
\hline $\begin{array}{c}\mathrm{M} \pm \mathrm{m} \\
\% \\
\mathrm{R}\end{array}$ & $\begin{array}{c}62 \pm 0,81 \\
80 \\
P \geq \\
0,05\end{array}$ & $\begin{array}{c}5,22 \pm 0 \\
03 \\
73,5 \\
\mathrm{P} \geq \\
0,05 \\
\end{array}$ & $\begin{array}{c}12,67 \pm 0,3 \\
6 \\
155,4 \\
P \geq 0,01\end{array}$ & 1 & 11 & - & - & 3 & 19 & 61 & 5 \\
\hline Group II & 66 & 5,67 & 10,8 & 1 & 8 & - & - & 5 & 29 & 53 & 4 \\
\hline is less & 68 & 5,72 & 10,4 & 1 & 7 & - & - & 4 & 31 & 52 & 5 \\
\hline affected & 66 & 5,66 & 11,0 & 1 & 9 & - & - & 5 & 24 & 55 & 6 \\
\hline & 70 & 5,80 & 10,3 & 1 & 7 & - & - & 4 & 32 & 52 & 4 \\
\hline $\begin{array}{c}\mathrm{M} \pm \mathrm{m} \\
\% \\
\mathrm{R}\end{array}$ & $\begin{array}{c}67,5 \pm 0 \\
95 \\
87 \\
P \geq \\
0,05\end{array}$ & $\begin{array}{c}5,71 \pm 0 \\
03 \\
80,4 \\
P \geq \\
0,05\end{array}$ & $\begin{array}{c}10,62 \pm, 01 \\
6 \\
130,3 \\
P \geq 0,05\end{array}$ & 1 & 7,75 & - & - & 4,5 & 29 & 53 & 4,75 \\
\hline Group & 76 & 6,99 & 8,3 & 1 & 5 & - & - & 6 & 35 & 50 & 3 \\
\hline III was & 78 & 7,02 & 8,2 & 1 & 4 & - & - & 6 & 38 & 47 & 4 \\
\hline undamag & 80 & 7,01 & 7,9 & 1 & 4 & - & - & 7 & 37 & 46 & 5 \\
\hline ed & 76 & 6,98 & 8,2 & 1 & 5 & - & - & 7 & 35 & 48 & 4 \\
\hline $\begin{array}{c}\mathrm{M} \pm \mathrm{m} \\
\%\end{array}$ & $\begin{array}{c}77,5 \pm 0 \\
95 \\
100\end{array}$ & $\begin{array}{c}7,1 \pm 0,0 \\
1 \\
100\end{array}$ & $\begin{array}{c}8,15 \pm 0,8 \\
100\end{array}$ & 1 & 4,5 & - & - & 6,5 & 36,25 & $\begin{array}{c}47,7 \\
5\end{array}$ & 4 \\
\hline
\end{tabular}


When we analyzed the results, the hemoglobin content in large horned animals strongly (group I) and low (group II) infected with echinococci increased by $13.0 \%$ in group I ( $R>$ $0.05)$ and by $20.0 \%$ in group II. ( $R>0.05)$ and decreased erythrocyte counts in group I by $19.6 \%(R>0.05)$, group II by $26.5 \%(R>0.05)$, and leukocyte counts in group I by $55,4 \%(R>0.01)$ and $30.3(R>0.05)$ in group II. The levels of basophils and monocytes in the leukoformula remained almost unchanged, but a decrease in the number of neurophils, as well as an increase in the number of eosinophils and lymphocytes were found.

Decrease in erythrocytes and hemoglobin in the blood of cattle infected with echinococcosis (20-30\%), increase in the number of leukocytes by 30-55\%, a significant increase in the number of eosinophils and lymphocytes in the leukoform, a decrease in neutrophils by $3.25-6.5 \%$, and lymphocytes - an increase of $5 \cdot 3-15.3 \%$. These changes were found to be consistent with the intensity of the invasion.

\section{CONCLUSION}

1. Echinococci were found in 18 heads (8.8\%) of 205 heads of horned animals examined in Samarkand region, and in 1 head (14.3\%) of 7 heads of horned animals inspected in Surkhandarya region.

2. Decrease in the amount of erythrocytes and hemoglobin in the blood of cattle infected with echinococcosis (by 20-30\%), increase in the number of leukocytes by $30-55 \%$, and a significant increase in the number of eosinophils and lymphocytes in the leukoform is a decrease in neutrophils (3.25$6.5 \%$ ). and an increase in lymphocytes by $5.3-$ $15.3 \%$.

\section{REFERENCES}

1. Aminzhanov $M$. "Echinococcosis is a dangerous disease." Journal "Agriculture of Uzbekistan" 2003, No. 5, -pp. 18-22.

2. O. Andreyanov. "Toxacorosis of carnivores in the conditions of natural biocenosis" / Collection of scientific papers, International educational methodological and scientific-practical conference dedicated to the 140th anniversary of the birth of Academician K.I. Skryabin. November 15-16, 2018. -pp. 46-49.

3. Arkhipov I.A. "Features of the use of anthelmintics on different species of animals." / Proceedings of the All-Russian Institute of Helminthology. Them K.I. Skryabin. 2001 volume 38, -pp. 3-24

4. Beer A.S., Ermolova R.S., Vaserin Yu.I. "Echinococcosis: methods research, treatment, prophylactic ". Moscow: 1990. -pp. $19-25$

5. Kovalenko F.P. et al. "Echinococcosis biology of pathogens, epizootology, prevention”, Journal “Veterinary” 2000, № 4, -pp. 46-48

6. Laipanov B.K. "Echinococcosis as a world epizootic, socio-economic and medicobiological problem, a way to solve it." / Collection of scientific papers. International educational methodological and scientific-practical conference dedicated to the 140th anniversary of the birth of Academician K.I. Skryabin. November 15-16, 2018. -pp. 186-190.

7. 7 . Matchanov N.M., Sagieva A.T. and Sadykov V.M. "Larval teniidosis of humans and karakul sheep ". Publishing House "Medicine" UzSSR. Tashkent 1977 -pp. 7982.33

8. Subbotina I.A., Bakiev B.N. "Echinococcosis and coenurosis of sheep - current state, Problems in Turkmenistan". / Collection of scientific papers. International educational 
methodological and scientific-practical conference dedicated to the 140th anniversary of the birth of Academician K.I. Skryabin. November 15-16, 2018. -pp. 306310

9. Ergashov E.X. etc. "Fight echinococcosis is a very dangerous disease." / Journal "Veterinary of Uzbekistan", 2000, № 3, pp. 3-6.

10. Bartelli G., Martini M. 1992. Ann. Inst. Super sanita, 28. № 4: -pp. 473 - 475. 